Article Type: Research Paper

\title{
Pengaruh Keberadaan Industri Hasil Tembakau (IHT) Terhadap Harga Rumah Menggunakan Pendekatan Hedonic Price: Studi Pada Kawasan Sekitar PR Sukun, Kudus, Jawa Tengah
}

Novyan Dewa Mepriyanto ${ }^{1}$ and Endah Saptutyningsih ${ }^{1}$

\begin{abstract}
Abstrak: Penelitian ini bertujuan untuk mengukur seberapa besar pengaruh keberadaan Industri Hasil Tembakau (IHT) terhadap harga rumah. Dampak perkembangan industri yang pesat dapat menimbulkan polusi, akibatnya dapat mempengaruhi harga jual rumah di sekitar lokasi industri. Subjek penelitian ini adalah warga desa yang bertempat tinggal di daerah Industri Hasil Tembakau (IHT) yaitu desa Gondosari, Kecamatan Gebog, Kabupaten Kudus. Metode penelitian ini menggunakan pendekatan hedonic price. Pengumpulan data primer menggunakan kuesioner dan wawancara kepada 265 responden yang dipilih dengan menggunakan metode purposive sampling. Hasil analisis menunjukan variabel jarak ke kota tidak berpengaruh terhadap harga jual rumah di Desa Gondosari, Kecamatan Gebog, Kabupaten Kudus. Sedangkan luas bangunan, jumlah kamar, ketersediaan taman, jarak ke industri, jarak sekolah, dan polusi air berpengaruh terhadap harga jual rumah di Desa Gondosari, Kecamatan Gebog, Kabupaten Kudus. Kata Kunci: Hedonic Price; Marginal Willingness to Pay; Harga Jual Rumah; Polusi Air.
\end{abstract}

ARTIKEL INI TERSEDIA DI:

http://journal.umy.ac.id/index.php/jerss

DOI: $10.18196 /$ jerss.030208

SITASI:

Mepriyanto, N. D., \&

Saptutyningsih, E. (2020).

Pengaruh Keberadaan Industri

Hasil Tembakau (IHT) Terhadap

Harga Rumah Menggunakan

Pendekatan Hedonic Price: Studi

Pada Kawasan Sekitar PR Sukun, Kudus, Jawa Tengah. Journal of Economics Research and Social

\section{Pendahuluan}

Kerusakan lingkungan hidup pada saat ini tidak terlepas dari peran serta manusia. Populasi manusia mempengaruhi keadaan alam. Dengan bertambahnya manusia, mendesak manusia untuk memproduksi produk untuk dikonsumsi dengan merusak alam yang ada di sekitarnya. Hasil dari kegiatan produksi tersebut mengeluarkan limbah yang dibuang ke lingkungan. Limbah inilah yang mengakibatkan kerusakan alam khususnya pada lingkungan hidup. Dalam kegiatan produksi tersebut terkadang manusia tidak memikirkan analisis mengenai dampak lingkungan (AMDAL).

Isu lingkungan hidup di Indonesia sampai saat ini menjadi perhatian seiring dengan pertumbuhan ekonomi dan pemanfaatan sumber daya alam sebagai salah satu penunjang terbesar dari sumber pendapatan negara ini. Ketika industrialisasi menjanjikan dapat menyerap tenaga kerja secara besar-besaran dan meningkatkan kesejahteraan bagi masyarakat 
Pengaruh Keberadaan Industri Hasil Tembakau (IHT) Terhadap Harga Rumah ...

akan tetapi industrialisasi juga mempunyai potensi membahayakan kesehatan, kesejahteraan masyarakat dan juga lingkungan sekitar kawasan industri tersebut.

Namun kini seiring dengan meningkatnya aktivitas pembangunan ekonomi dan pertumbuhan penduduk mengakibatkan tingginya tekanan terhadap lingkungan hidup yang pada akhirnya akan merusak lingkungan itu sendiri. Sungai sebagai bagian dari lingkungan hidup saat ini kondisinya memprihatinkan. Kondisi-kondisi sungai di Indonesia banyak yang mulai kritis, terjadi kecenderungan perubahan ekosistem sungai yang ditunjukkan dengan adanya degradasi kuantitas dan kualitas air.

Di lain sisi lingkungan industri memberikan dampak yang positif bagi pertumbuhan ekonomi Indonesia. Salah satunya di Kabupaten Kudus yang saat ini terhitung sebagai kabupaten industri. Hal ini disebabkan banyaknya jumlah industri besar di Kabupaten Kudus. Salah satu industri terbesar di Kabupaten Kudus yaitu IHT (Industri Hasil Tembakau) atau rokok. Berkembangnya industri rokok di Kabupaten Kudus mengalami kenaikan yang sangat pesat dan menjadikan Kabupaten Kudus mendapatkan julukan sebagai "Kota Kretek". Menurut Hasibuan (2015) Industri sendiri dari segi mikro yaitu suatu perkumpulan usaha atau kegiatan pengolahan bahan mentah menjadi barang jadi. Sedangkan dari segi makro yakni industri dapat memilik nilai tambah. Batasan industri secara mikro merupakan kumpulan suatu usaha atau perusahaan yang menghasilkan barang dan jasa secara makro yaitu dapat menghasilkan pendapatan. Industri merupakan aspek terpenting dalam mempengaruhi perkembangan suatu negara.

\section{Tinjauan Pustaka}

Beberapa pembahasan yang serupa dengan penelitian ini juga ditemukan pada beberapa jurnal seperti Hutomo (2010), ia menganalisa mengenai penetapan harga jual unit apartemen Puncak Permai, Surabaya. Dalam menentukan harga jual, ia menggunakan dua metode yaitu metode analisa biaya dan analisa permintaan pasar. Metode analisa biaya menggunakan metode analisa titik impas sedangkan metode analisa permintaan pasar diperoleh melalui survey langsung. Serupa dengan penelitian Josep (2013). Dalam menetapkan harga jual rumah di perumahan Grand Meridian, ia menggunakan dua metode yang sama dengan Hutomo. Metode analisa biaya menggunakan metode analisa ekuilibrium, sedangkan metode analisa permintaan pasar diperoleh melalui survei langsung. Penelitian ini memiliki kesamaan metode dalam menetapkan harga jual, yaitu metode analisa titik impas dan permintaan pasar, namun mempunyai perbedaan dalam obyek yang diteliti (Josep, 2013).

Farber (1998) memberikan survei literatur tentang dampak fasilitas yang tidak diinginkan pada nilai-nilai rumah. Kekhawatiran tersebut berkisar dari kekhawatiran tentang risiko kesehatan hingga citra publik masyarakat. Mereka dapat memanifestasikan diri mereka di pasar properti karena kemungkinan besar orang bersedia membayar lebih untuk tinggal di lokasi yang jauh dari anggapan tidak nyaman. Survei tersebut menegaskan bahwa fasilitas yang tidak diinginkan (misalnya, tempat pembuangan sampah, lokasi limbah, fasilitas manufaktur berbahaya) mengurangi nilai 
Pengaruh Keberadaan Industri Hasil Tembakau (IHT) Terhadap Harga Rumah ...

properti di sekitarnya. Efek merugikan ini berkurang seiring dengan jarak, mengakibatkan peningkatan nilai properti seiring bertambahnya jarak dari situs ini. Selain itu, efek nilai properti yang merugikan ini tampaknya relatif terlokalisasi. Contoh lain dapat ditemukan dalam sejumlah penelitian yang telah menunjukkan efek pada nilai properti karena situs yang terkontaminasi. Studi-studi ini (misalnya, Smolen, Moore, \& Conway, 1991; Mendelsohn et al., 1992) telah melaporkan dampak merugikan pada nilai mulai dari yang terendah 0,24 persen hingga setinggi 25 persen, tergantung pada tingkat polusi dan lokasi dari properti.

Visser dan van Dam (2006) telah menganalisis pasar perumahan di Belanda secara keseluruhan dan telah memfokuskan antara lain pada kontribusi karakteristik lingkungan terhadap variasi harga rumah. Dengan mempertimbangkan berbagai karakteristik di sekitar langsung (50 meter) dari tempat tinggal yang bersangkutan (misalnya, keberadaan taman, ruang terbuka dan lahan industri, sifat dan kualitas bangunan, status sosial lingkungan, jarak ke layanan, dan infrastruktur), mereka menyimpulkan bahwa nilai properti dipengaruhi secara positif oleh kualitas sekitarnya dalam hal ketersediaan fasilitas. Misalnya, rumah, yang terletak di lingkungan hijau dan padat rendah, secara signifikan lebih tinggi nilainya daripada rumah di daerah padat tinggi dengan kurangnya taman dan ruang terbuka. Sebaliknya, kata-kata kotor, seperti keberadaan lahan industri dan dekat jalan raya, berdampak negatif terhadap harga. Temuan ini menunjukkan bahwa efek yang berasal dari (dis-) fasilitas beroperasi terutama pada skala lokal, yang menegaskan gagasan bahwa dampak berkurang dengan jarak.

Hasil ini dikonfirmasi oleh studi yang lebih rinci oleh Rouwendal dan Straaten (2008) di Belanda, Dekkers dan van der Straaten (2008); dan Debrezion, Pels dan Rietveld. (2006). Taman umum di sekitar rumah meningkatkan nilainya. Namun, karena situasi pasar perumahan yang ketat di Amsterdam, kesediaan untuk membayar ruang terbuka paling rendah di kota ini, dibandingkan dengan kota-kota lain yang dipertimbangkan. Studi kedua menyelidiki pengaruh kebisingan pesawat terbang pada harga rumah di daerah perkotaan sekitar Bandara Amsterdam. Mengontrol berbagai sumber kebisingan lalu lintas, lalu lintas udara menghasilkan dampak harga terbesar, diikuti oleh lalu lintas kereta api dan lalu lintas jalan raya. Akhirnya, Debrezion dkk (2006) menganalisis pengaruh aksesibilitas yang disediakan oleh stasiun kereta api Belanda terhadap harga rumah pemukiman. Studi tersebut menunjukkan bahwa harga rumah menurun dengan jarak ke stasiun kereta api, memperlihatkan efek kedekatan yang positif. Efek ini ditingkatkan ketika frekuensi layanan kereta di stasiun meningkat. Oleh karena itu, studi ini memberikan wawasan tentang efisiensi kebijakan publik dalam hal penyediaan ruang terbuka yang optimal, langkah-langkah pengurangan kebisingan pesawat terbang, dan aksesibilitas stasiun kereta api.

\section{Metode Penelitian}

Jenis penelitian yang dilakukan merupakan jenis penelitian kuantitatif non eksperimental yaitu menggunakan metode kuantitatif survei. Peneliti melakukan 
Pengaruh Keberadaan Industri Hasil Tembakau (IHT) Terhadap Harga Rumah ...

pengumpulan data dengan cara menyebarkan kuisioner kepada responden yang telah ditentukan dengan menggunakan teknik pengambilan purposive sampling.

Populasi dalam penelitian ini adalah warga Desa Gondosari, Kecamatan Gebog, Kabupaten Kudus di sekitar PR. Sukun dengan jumlah keseluruhan penduduk pada tahun 2017 dengan berjumlah 12.388 jiwa. Karena dalam pemilihan sampel mempunyai tujuan untuk memilih sampel yang mampu memberikan informasi mengenai harga jual rumah di Desa Gondosari, Kecamatan Gebog, Kabupaten Kudus, maka diperoleh jumlah sampel yang akan digunakan sebagai responden oleh peneliti yang ditentukan besarnya sampel pada penelitian ini menggunakan rumus Isaac dan Michele dengan tingkat signifikasi $10 \%$ adalah berjumlah 265 responden.

Penelitian ini dilakukan di Desa Gondosari, Kecamatan Gebog, Kabupaten Kudus. Penelitian ini dimulai pada tanggal 5 Januari 2019 hingga tanggal 5 Maret 2019. Penelitian ini dilakukan dengan metode survei yaitu dengan cara membagikan angket kuesioner. Metode angket yaitu teknik pengumpulan data yang di laksanakan dengan cara membagikan atau menyebar angket yang berisi beberapa pertanyaan kepada responden atau narasumber (Sugiono, 2004).

\section{Hasil dan Pembahasan}

Sebelum melakukan uji regresi, perlu dilakukan beberapa pengujian asumsi klasik untuk menguji tingkat keabsahan data. Uji yang pertama yakni normalitas, uji ini adalah pengamatan terdistribusi secara normal atau tidak, uji ini menggunakan kolmogorov smirnov. Hasil uji Normalitas dapat dilihat pada tabel di bawah ini.

Tabel 1 Hasil Uji Normalitas

\begin{tabular}{ll} 
& $\begin{array}{l}\text { Kolmogorov-Smirnov } \\
\text { Signifikansi }\end{array}$ \\
\hline Unstandardized Residual & 1.051 \\
\hline Sumber : Data Primer diolah dengan SPSS, 2019
\end{tabular}

Berdasarkan hasil pada tabel 1 dapat diketahui bahwa nilai asymp.sig sebesar 1.051 lebih besar dari 0,05 sehingga dapat disimpulkan bahwa data tersebut terdistribusi normal. Suatu asumsi penting dari model regresi linier klasik adalah bahwa gangguan (disturbance) yang muncul dalam regresi adalah homoskedastisitas, yaitu semua gangguan tadi mempunyai varian yang sama. Hasil uji Heteroskedastisitas dapat dilihat pada tabel berikut:

Berdasarkan Tabel 2 dapat diketahui bahwa nilai probabilitas lebih besar dari 5\%, dengan demikian variabel yang diajukan dalam penelitian tidak terjadi heterokedasitas. Uji multikolinieritas bertujuan untuk mengetahui apakah dalam model regresi ditemukan adanya korelasi antar variabel bebas. Model regresi yang baik seharusnya tidak terjadi korelasi antar variabel bebas. Untuk mengetahui ada atau tidaknya 
Pengaruh Keberadaan Industri Hasil Tembakau (IHT) Terhadap Harga Rumah ...

multikolinieritas maka dapat dilihat dari nilai Variance Inflation Factor (VIF) dan tolerance $(\alpha)$.

Tabel 2 Uji Heteroskedastisitas

\begin{tabular}{lccl}
\hline \multicolumn{1}{c}{ Variabel } & Sig & Batas & \multicolumn{1}{c}{ Keterangan } \\
\hline Luas Bangunan & 0,270 & $>0,05$ & Tidak Terjadi Heteroksiditas \\
Jumlah Kamar & 0,508 & $>0,05$ & Tidak Terjadi Heteroksiditas \\
Ketersediaan Taman & 0,102 & $>0,05$ & Tidak Terjadi Heteroksiditas \\
Jarak ke Industri & 0,606 & $>0,05$ & Tidak Terjadi Heteroksiditas \\
Jarak ke Kota & 0,062 & $>0,05$ & Tidak Terjadi Heteroksiditas \\
Jarak ke Sekolah & 0,835 & $>0,05$ & Tidak Terjadi Heteroksiditas \\
Polusi Air & 0,980 & $>0,05$ & Tidak Terjadi Heteroksiditas \\
\hline
\end{tabular}

Sumber : Data Primer diolah dengan SPSS, 2019

Tabel 3 Uji Multikolinearitas

\begin{tabular}{lccl}
\multicolumn{1}{c}{ Variabel } & Tolerance & VIF & Keterangan \\
\hline Luas Bangunan & 0,534 & 1.872 & Tidak Terjadi Heteroksiditas \\
Jumlah Kamar & 0,563 & 1.777 & Tidak Terjadi Heteroksiditas \\
Ketersediaan Taman & 0,961 & 1.041 & Tidak Terjadi Heteroksiditas \\
Jarak ke Industri & 0,913 & 1.095 & Tidak Terjadi Heteroksiditas \\
Jarak ke Kota & 0,992 & 1.008 & Tidak Terjadi Heteroksiditas \\
Jarak ke Sekolah & 0,991 & 1.009 & Tidak Terjadi Heteroksiditas \\
Polusi Air & 0,934 & 1.071 & Tidak Terjadi Heteroksiditas \\
\hline
\end{tabular}

Sumber : Data Primer yang diolah dengan SPSS, 2019

Berdasarkan pada hasil Tabel 3 semua variabel independen tidak terjadi multikolinearitas terhadap variabel dependen karena VIF kurang dari 10.

Tabel 4 Hasil Regresi Linier Berganda

\begin{tabular}{|c|c|}
\hline Variabel & Koefisien \\
\hline \multirow[t]{2}{*}{ Intercept } & 17,527 \\
\hline & $(0,332)$ \\
\hline \multirow[t]{2}{*}{ LnLuasBangunan (LB) } & $0,257^{*}$ \\
\hline & $(0,011)$ \\
\hline \multirow[t]{2}{*}{ LnJumlahKamar (JK) } & $0,095^{*}$ \\
\hline & $(0,015)$ \\
\hline \multirow[t]{2}{*}{ AdaTidaknyaTaman (ATT) } & $0,019 * *$ \\
\hline & $(0,008)$ \\
\hline \multirow[t]{2}{*}{ LnJarakKelndustri (JKI) } & $0,013^{* *}$ \\
\hline & $(0,006)$ \\
\hline \multirow[t]{2}{*}{ LnJarakKeKota (JKK) } & 0,016 \\
\hline & $(0,032)$ \\
\hline \multirow[t]{2}{*}{ LnJarakKeSekolah (JKS) } & $0,027 * *$ \\
\hline & $(0,011)$ \\
\hline \multirow[t]{2}{*}{ LnPolusiAir (PA) } & $0,138 * * *$ \\
\hline & $(0,081)$ \\
\hline F Hitung & 228,215 \\
\hline Harga Jual Rumah $(\mathrm{Y})$ & Variabel dependen \\
\hline
\end{tabular}

Ket: ${ }^{*}<0.10 \% ; * *<0,05 ; * * *<0,01$

Sumber: Data diolah 
Pengaruh Keberadaan Industri Hasil Tembakau (IHT) Terhadap Harga Rumah ...

Berdasarkan uji-t pada Tabel 4, dapat disimpulkan bahwa variabel luas bangunan dan jumlah kamar berpengaruh secara signifikan terhadap harga jual rumah pada level 1 persen atau 0,01. Pada variabel ketersediaan taman, jarak ke industri, dan jarak ke sekolah berpengaruh secara siginfikan terhadap harga jual rumah pada level 5 persen atau 0,05 . Variabel polusi air berpengaruh secara signifikan terhadap harga jual rumah pada level 10 persen atau 0,1. Sedangkan, variabel jarak ke kota tidak mempengaruhi secara signifikan terhadap harga jual rumah.

Turunan pertama dari fungsi hedonic price dapat diartikan sebagai fungsi harga marginal implisit untuk suatu barang lingkungan. Fungsi harga marjinal implisit untuk konsentrasi $\mathrm{pH}$ yang diperoleh untuk air sumur warga di Desa Gondosari dengan mengambil turunan dari fungsi harga hedonic price sehubungan dengan $\mathrm{pH}$ (X7) diberikan sebagai berikut :

$$
\text { implisit harg } a=343396226,42 .\left(\frac{1}{0.138}\right)=2.488 .378 .452
$$

Oleh karena itu, marjinal harga implisit untuk memperbaiki kadar $\mathrm{pH}$ air bersih dihitung berjumlah Rp. 2.488.378.452,00. Hasil ini dengan jelas mengidentifikasi kualitas air sebagai faktor penting, bersama dengan karakteristik struktural dan lingkungan, dalam menentukan permintaan untuk transaksi harga jual rumah di Desa Gondosari, Kecamatan Gebog, Kabupaten Kudus.

Uji $\mathrm{F}$ dilakukan bertujuan untuk mengetahui variabel independen memiliki pengaruh atau tidak terhadap variabel independen adalah apabila $\mathrm{F}$ hitung lebih besar dari $\mathrm{F}$ tabel maka $\mathrm{HO}$ ditolak dan $\mathrm{H} 1$ diterima yang artinya variabel independen secara bersamasama berpengaruh terhadap variabel dependen. Berikut hasil uji $\mathrm{F}$ dalam penelitian ini:

Tabel 5 Hasil Uji Variabel Secara Bersama-sama (Uji F)

\begin{tabular}{llllll} 
Model & Sum of Squares & Df & Mean Square & F & Sig. \\
\hline Regression & 5.854 & 7 & .836 & 228.215 & $.000^{\text {b }}$ \\
Residual & .942 & 257 & .004 & & \\
Total & 6.796 & 264 & & & \\
\hline
\end{tabular}

Sumber: Data Primer yang diolah dengan SPSS, 2019

Berdasarkan hasil analisis regresi linier berganda Uji $F$ diketahui bahwa nilai signifikan sebesar 0,000 . Dengan menggunakan tingkat kepercayaan $(\alpha)=0,05$, maka nilai signifikan penelitian ini $0,000<0,05$. Maka dapat disimpulkan bahwa $\mathrm{H} 1$ diterima dan berarti bahwa variabel independen luas bangunan, jumlah kamar, ketersediaan taman, jarak ke industri, jarak ke kota, jarak ke sekolah, dan polusi air secara bersama-sama memiliki pengaruh terhadap variabel dependen yaitu harga jual rumah dalam penelitian ini.

Uji koefisien determinasi merupakan pengujian untuk mengetahui bagaimana variabel independen dalam menjelaskan variabel dependen dengan model regresi tersebut. Nilai koefisien relasi dalam analisis regresi linier berganda ditunjukkan dengan nilai R. Berikut adalah hasil uji koefisien determinasi dalam penelitian ini: 
Pengaruh Keberadaan Industri Hasil Tembakau (IHT) Terhadap Harga Rumah ...

Tabel 6 Hasil Uji Koefisien Determinasi

\begin{tabular}{ccccc|}
\hline Model & $\mathrm{R}$ & $\mathrm{R}$ Square & Adjusted R Square & $\begin{array}{c}\text { Std. Error of } \\
\text { Estimate }\end{array}$ \\
\hline 1 & $.928^{\mathrm{a}}$ & .861 & .858 & $\mathbf{0 6 0 5 4}$ \\
\hline
\end{tabular}

Sumber : Data Primer yang diolah dengan SPSS, 2019

Berdasarkan hasil perhitungan Tabel 6, menunjukkan bahwa nilai $\mathrm{R}$ sebesar 0,928, sehingga hubungan antara variabel independen yaitu luas bangunan, jumlah kamar, ketersediaan taman, jarak ke industri, jarak ke kota, jarak ke sekolah, dan polusi air memiliki hubungan yang kuat. Kemudian, nilai uji koefisien determinasi dapat dilihat dari nilai adjusted $R$ Square.

Dari Tabel 6 bahwa nilai adjusted $R 2$ dalam penelitian ini sebesar 0,858. Maka, ini berarti bahwa variabel independen dalam penelitian ini yaitu luas bangunan (LB), jumlah kamar (JK), ketersediaan taman (ATT), jarak ke industri (JKI), jarak ke kota (JKK), jarak ke sekolah (JKS), dan polusi air (PA) mampu menjelaskan variabel dependen harga jual rumah $(Y)$ sebesar 85,8 persen. Sehingga sisanya 14,2 persen di jelaskan oleh variabel lain di luar model penelitian ini.

Dalam penelitian ini menunjukkan bahwa luas bangunan, jumlah kamar, ketersediaan taman, jarak ke industri, dan jarak ke sekolah berpengaruh terhadap harga jual rumah di Desa Gondosari, Kecamatan Gebog, Kabupaten Kudus. Sedangkan variabel jarak ke kota dan polusi air di Desa Gondosari, Kecamatan Gebog, Kabupaten Kudus tidak berpengaruh terhadap harga jual rumah di Desa Gondosari, Kecamatan Gebog, Kabupaten Kudus.

Variabel luas bangunan dalam penelitian ini memiliki pengaruh yang positif dan signifikan terhadap harga jual rumah di Desa Gondosari, Kecamatan Gebog, Kabupaten Kudus. Penelitian ini sejalan dengan yang dilakukan oleh Saptutyningsih (2013) yang menyatakan bahwa luas bangunan dapat mempengaruhi harga jual rumah masyarakat. Hal ini berarti bahwa jika semakin tinggi unit cost lahannya maka akan semakin bertambah harga jual rumah di Desa Gondosari. Peningkatan harga jual rumah terjadi apabila luas bangunan tersebut semakin besar sesuai dengan pernyataan oleh Saptutyningsih (2013) yang menyatakan bahwa luas bangunan dapat mempengaruhi harga jual rumah masyarakat.

Hal yang sama terdapat pada penelitian yang dilakukan oleh Ondrina (2012) dan Syabri (2011), yang mengatakan bahwa luas bangunan sangat berpengaruh dalam menentukan tingkat harga jual rumah. Hal ini dikarenakan apabila luas bangunan itu besar maka akan meningkatkan harga serta keinginan lebih masyarakat untuk memiliki rumah tersebut.

Variabel jumlah kamar dalam penelitian ini memberikan pengaruh yang positif dan signifikan terhadap harga jual rumah. Penelitian ini sejalan dengan Pertiwi (2014); Komarova (2009) yang menjelaskan bahwa jumlah kamar mempengaruhi harga jual rumah. Hal ini berarti bahwa jika semakin besar unit cost setiap ruangan dan banyaknya jumlah kamar di rumah maka akan semakin tinggi tingkat harga jual rumah. Penelitian 
Pengaruh Keberadaan Industri Hasil Tembakau (IHT) Terhadap Harga Rumah ...

lainnya yang sesuai yakni, Eilers dan Elhorst (2013); Murty dan Gulati (2004) yang menjelaskan bahwa jumlah kamar mempengaruhi harga jual rumah. Hal ini dikarenakan kamar merupakan ruangan yang penting di dalam rumah. Semakin banyak jumlah kamar maka akan semakin besar juga untuk menampung keluarga di rumah.

Variabel ketersediaan taman dalam penelitian ini memberikan pengaruh yang positif dan signifikan terhadap harga jual. Hal ini berarti taman merupakan fasilitas yang berpengaruh pada tingkat harga jual rumah. Jika semakin dekat keberadaan taman di sekitar rumah maka dapat menambah nilai fasilitas dan dapat di manfaatkan untuk area bermain. Serta memberikan kualitas udara yang baik di sekitar rumah. Hal tersebut dapat meningkatkan harga jual rumah tersebut.

Penelitian ini juga sejalan dengan Dziauddin Powe, dan Alvanides (2013); Lin dan Hwang (2003) dan Saptutyningsih (2013) yang menjelaskan bahwa apabila terdapat taman sebagai area bermain dapat meningkatkan fasilitas perumahan maka akan meningkatkan juga nilai tambah harga jual rumah di daerah tersebut. Hal ini dikarenakan bahwa taman dapat memberikan nilai jual lebih untuk pembeli.

Variabel jarak ke industri dalam penelitian ini memberikan pengaruh positif dan signifikan terhadap harga jual. Hal dikarenakan rumah yang berlokasi di dekat industri sangat mengutungkan bagi pengembang perumahan. Penelitian ini didukung oleh penelitian yang dilakukan oleh Syabri (2011) dan Murty, Gulati, dan Banerjee (2003) yang menyatakan bahwa jarak ke industri dengan harga jual rumah mempunyai hubungan. Hal ini karena banyaknya pekerja industri yang memilih untuk tinggal di sekitar lokasi industri karena waktu tempuh bekerja mereka dekat dan mempunyai banyak waktu untuk beristirahat di rumah.

Hasil yang berbeda muncul dari variabel jarak ke kota. Hal ini dikarenakan bahwa lokasi menjadi pilihan terakhir dalam membeli rumah. Sehingga walaupun lokasi rumah jauh dari kota tidak memberikan efek harga jual rumah yang signifikan, sesuai dengan penelitian Putri dan Jamal (2014); Kurniawan (2018. Berbeda dengan penelitian lainnya yang mengatakan jarak ke kota memiliki pengaruh signifikan dalam menentukan harga jual rumah. Hal ini dikarenakan bahwa semakin dekat dengan kota maka akan semakin menunjang dalam akses ke lokasi pekerjaan (Putri, 2012).

Variabel jarak ke sekolah dalam penelitian ini memiliki pengaruh yang positif dan signifikan terhadap harga jual. Penelitian ini sejalan dengan Saptutyningsih (2013); Lin dan Hwang (2003) Rahmawati, Ekwarso, dan Taryono (2017) dan Komarova (2005) yang menyatakan bahwa jarak ke sekolah mempengaruhi harga jual rumah. Hal ini berarti bahwa semakin dekat dengan fasilitas penunjang pendidikan maka akan semakin tinggi nilai jual rumah.

Variabel polusi air dalam penelitian ini memiliki pengaruh yang positif signifikan terhadap harga jual. Hal ini diduga karena rata-rata air sumur di daerah tersebut yang kadar $\mathrm{pH}$ nya tidak memenuhi baku mutu tersebut hanya digunakan sebagai mencuci 
dan memasak saja. Kemudian air bersih untuk mandi dan konsumsi rata-rata lebih mengandalkan air bersih dari PDAM (Perusahaan Daerah Air Minum).

Penelitian ini didukung dengan penelitian yang dilakukan oleh Pertiwi (2014); Komarova (2009); Putri (2012); Saptutyningsih (2013) dan Moaz (2005) yang mengatakan bahwa karakteristik lingkungan yaitu tidak adanya polusi memberikan dampak yang positif dan signifikan terhadap harga rumah. PR. Sukun sadar bahwa kelestarian lingkungan harus dijaga supaya memberikan daya dukung kehidupan masyarakat sekitar dan tentunya untuk mendukung kelangsungan usaha serta tidak segan untuk menginvestasikan dananya dalam pengelolaan limbah dengan cara membangun instalasi pengelolaan limbah sesuai dengan standar pemerintah dan memberikan penghijauan di sekitar lingkungan pabrik yang baik.

\section{Kesimpulan}

Dari uraian di atas, dapat disimpulkan beberapa hal yakni, pertama, Marginal Willingness to Pay berasal dari harga implisit untuk mengurangi $\mathrm{pH}$ air bersih. Dihitung dengan rumus harga implisit yang berjumlah Rp. 2.488.378.452,00. Hasil ini dengan jelas mengidentifikasi kualitas air sebagai faktor penting, bersama dengan karakteristik struktural dan lingkungan, dalam menentukan permintaan untuk transaksi harga jual rumah di Desa Gondosari, Kecamatan Gebog, Kabupaten Kudus.

Kedua, hasil uji regresi linier berganda menunjukkan terdapat faktor-faktor yang mempengaruhi harga jual rumah yaitu luas bangunan, jumlah kamar, ketersediaan taman, jarak ke industri, jarak ke sekolah. Sedangkan jarak ke kota tidak memiliki pengaruh terhadap harga rumah di Desa Gondosari. Ketiga, jarak ke kota tidak mempengaruhi harga jual rumah di Desa Gondosari dikarenakan banyak masyarakat yang bekerja di sekitar PR. Sukun tersebut yang jaraknya jauh dari kota. Masyarakat lebih memilih tinggal di sekitar daerah PR. Sukun dikarenakan lamanya jam bekerja mereka, maka masyarakat lebih memilih tinggal di dekat dengan lokasi pekerjaan mereka agar waktu untuk istirahat mereka tidak berkurang.

Keempat, luas bangunan, jumlah kamar, ketersediaan taman memiliki pengaruh positif terhadap harga jual rumah di Desa Gondosari. Luas, banyaknya ruang kamar, serta ketersediaan taman di sekitar bangunan dapat menambah harga jual. Hal ini dikarenakan bangunan yang memiliki luas yang besar, ruang kamar yang banyak, serta dekat dengan taman maka akan meningkatkan minat masyarakat untuk membeli rumah tersebut. Kelima, jarak ke industri dan jarak ke sekolah memiliki pengaruh positif terhadap harga jual rumah di Desa Gondosari. Dari segi bisnis, rumah yang berlokasi dekat dengan PR. Sukun sangat menguntungkan sehingga para pengembang perumahan diharapkan lebih mengembangkan pemukiman berwawasan lingkungan. Serta PR. Sukun juga menjamin kualitas lingkungan sekitar pabriknya baik dan tidak segan memberikan investasinya untuk lingkungan sekitarnya. 
Pengaruh Keberadaan Industri Hasil Tembakau (IHT) Terhadap Harga Rumah ...

Kesimpulan yang terakhir, polusi air memiliki pengaruh positif terhadap harga jual rumah di Desa Gondosari. Apabila pH air di daerah tersebut mendekati rata-rata maksimal pH maka akan menaikan harga rumah tersebut. Hal ini dikarenakan air merupakan kebutuhan primer di rumah tangga yang harus tersedia dan terpenuhi dengan baik.

Dalam hal saran, diharapkan bagi penjual rumah dapat menaikan harga jual bangunannya berdasarkan luas bangunan yang mereka miliki. Apabila semakin luas bangunan maka akan semakin tinggi dalam menetapkan harga jual rumah. Serta saran bagi calon pembeli untuk mempersiapkan budget rumah yang lebih apabila ingin memiliki luas bangunan yang di lebih luas.

Dalam hal saran, pengembang serta pembeli harus memperhatikan mengenai variabel yang telah diuraikan sebelumnya. Dari segi pengembang, perlu memperhatikan cara menentukan harga berdasarkan fasilitas yang disediakan. Sedangkan dari segi pembeli, perlu untuk menyesuaikan dana yang dimiliki terkait rumah yang ingin dimiliki.

\section{Daftar Pustaka}

Debrezion, G., E. Pels \& P. Rietveld. (2006). Impact of Railway Station on Dutch Residential Housing Market. Tinbergen Institute Discussion Paper, no. TI 2006-031/3, 1 24. Diakses dari https://papers.tinbergen.nl/06031.pdf

Dekkers, J., \& van der Straaten, W. (2008). Monetary Valuation of Aircraft Noise; A Hedonic Analysis around Amsterdam Airport. Tinbergen Institute Discussion Paper, no. TI 2008-064/3. Diakses dari http://hdl.handle.net/10419/87013

Dziauddin, M. F., Powe, N., \& Alvanides, S. (2015). Estimating the Effects of Light Rail Transit (LRT) System on Residential Property Values Using Geographically Weighted Regression (GWR). Applied Spatial Analysis and Policy, 8(1), 1-25. https://doi.org/10.1007/s12061-014-9117-z

Eilers, L., \& Elhorst, J., Paul. (2015). Spatial Dependence in Apartmet Offering Prices in Hamburg, Germany. Netherlands: Journal Department of Economics, Econometrics and Finance. Diakses dari https://editorialexpress.com/cgibin/conference/download.cgi?db name=IAAE2015\&paper id=664

Farber, S. (1998). Undesirable Facilities and Property Values: A Summary of Empirical Studies. Ecological Economics 24, 1-14. https://doi.org/10.1016/S0921$\underline{8009(97) 00038-4}$

Hutomo, P. (2010). Analisa Penetapan Harga Jual Unit Apartemen Puncak Permai di Surabaya. Skripsi. Teknik Sipil, Institut Teknologi Sepuluh November.

Josep, A. A. (2013). Analisa Penetapan Harga Jual Unit Rumah pada Proyek Perumahan Grand

Komarova, V. (2009). Valuing Environmental Impact of Air Pollution in Moscow with Hedonic Prices. World Academy of Science: Engineering and Technology.

Kurniawan, Y D. (2018). Analisis Faktor-Faktor Yang Mempengaruhi Pembelian Rumah di Kota Madiun. Thesis Universitas Muhammadiyah Surakarta.

Lin, J. J., \& Hwang, C. H. (2003). Analysis of Property Prices Before and After the Opening of the Taipei Subway System. Taipei: Springer-Verlag.

Moaz, A A. (2005). Hedonic Valuation of Marginal Willingness to Pay for Air Quality in Metropolitan Damascus. Forum of International Development Studies. 
Murty, M. N., \& Gulati, S.C. (2004). A Generalized Method of Hedonic Prices: Measuring Benefits from Reduced Urban Air Pollution. Delhi University Enclave: Institute of Economic Growth, Delhi-110007.

Murty, M., Gulati, S., \& Banerjee, A. (2003). Hedonic Property Prices and Valuation of Benefits from Reducin Urban Air Pollution in India. Delhi University Enclave: Institute of Economic Growth, 1-27.

Ondrina N, Elfia. (2012). Analysis of Factors Affecting The Housing Prices in Pekanbaru City ; The Application of Hedonic Price Method. Skripsi Universitas Riau.

Pertiwi, D S. (2014). Pengaruh Keberadaan PT Konimex Terhadap Harga Rumah Menggunakan Perhitungan Hedonic Price (Studi Pada Kawasan Sekitar PT Konimex, Sukoharjo, Jawa Tengah). Skripsi: Universitas Sebelas Maret.

Putri, H., \& Jamal, A. (2014). Faktor-Faktor Yang Mempengaruhi Pemilihan Lokasi Perumahan di Kota Banda Aceh. Jurnal Ekonomi dan Kebijakan Publik. 1(2), 55-61. http://www.jurnal.unsyiah.ac.id/EKaPI/article/view/3708/0

Putri, M S L. (2012). Analisis Faktor Penentu Harga Rumah Di Indonesia: Pendekatan Harga Hedonik. Thesis: Universitas Gajah Mada.

Rahmawati, K., Ekwarso, H., \& Taryono. (2017). Analisis Penetapan Harga Jual Rumah Menggunakan Metode Hedonic Price Pada Perumahan Tipe Menengah di Kota Pekanbaru. Jurnal Online Mahasiswa Fakultas Ekonomi Universitas Riau. 4(1), 1255-1265. Diakses dari https://jom.unri.ac.id/index.php/JOMFEKON/article/view/13474

Rouwendal, J., \& van der Straaten, J. W. (2008). The Costs and Benefits of Providing Open Space in Cities. (TI Discussion paper; No. TI 2008-01-07). Amsterdam: Tinbergen Instituut (TI).

Saptutyningsih, E. (2013). Impact of Air Pollution On Property Values: A Hedonic Price Study. Yogyakarta: Jurnal Ekonomi Pembangunan, 14(1), 52-65. https://doi.org/10.23917/jep.v14i1.150

Saptutyningsih, E., \& Basuki, A T. (2010). Penilaian Ekonomi Dampak Polusi Udara Perkotaan Di Provinsi Daerah Istimewa Yogyakarta. Hal 29-30.

Smolen, G.E., Moore, G., \& Conway, L.V. (1991) Economic Effects of Hazardous Waste Landfills on Surrounding Real Estate Values in Toledo, Ohio, Ohio State University, Research report, no. 44, Center for Real Estate Education and Research, Ohio.

Syabri, I. (2011). The Influence of Railway Station on Residential Property Values-Spatial Hedonic Approach The Case of Serpong's Railway Station. Jumal Teknik Sipil. 18(3), 292-300. http://dx.doi.org/10.5614\%2Fjts.2011.18.3.7

Visser, P. and van Dam, F. (2006) De Prijs van de Plek: Woonomgeving en Woningprijs, Rotterdam/ Den Haag: NAi Uitgevers/RPB (in Dutch). 